\title{
The Contextual Accounting Learning Management Based On Lesson Study At Senior High School
}

\author{
Suyatmini ${ }^{1}$, Sutama $^{2}$, Wafrotur Rohmah ${ }^{3}$, Titik Asmawati ${ }^{4}$

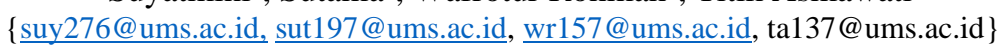 \\ Universitas Muhammadiyah Surakarta, Surakarta, Indonesia
}

\begin{abstract}
The research aims to analyze and describe the contextual accounting learning management that is done by the accounting teachers of Senior High School at Surakarta city. This research used research and development approach . The research subject was Senior High School accounting to teachers at Surakarta city. Data gathering method used: interview, observation and documentation. Data analysis technique used interactive analysis involving data gathering, data reduction, display, and verification. Data validity used triangulation method and sources. The research results showed that contextual accounting learning management that is done by Senior High School accounting teachers at Surakarta city is begun by making learning leading planning that is focus on syllabus, all teachers have not developed learning conducting planning independently. Most of them in education performing accounting still tend to use ceramah method, giving task and item exercise. Teachers still having problems in contextual accounting learning, Teachers have not fully understood and master contextual accounting learning. Teachers have not usual to link learning material with their real-life problems. Interaction management begin entering the class until the closing activity is dominated by the teachers (teacher center). Learning material management is conducted by an academic calendar that is established by the headmaster. Learning evaluation is done through Oral, written and giving task/assignment.
\end{abstract}

Keywords: accounting; contextual; learning; lesson study; management.

\section{Introduction}

Stepping from the information, and communication technology development that is demanded the accounting learning at the level of education set, especially Senior High School (SMA) that is in line with the progressing of science, knowledge and technology (IPTEK). Senior High School students, after completing their study tend to continue to the university. Therefore, accounting lessons curriculum should be arranged and prepared in a good way so that Senior High School students' graduation have can to develop their science and knowledge at the university or to help the society. The main target of the accounting lesson is preparing accounting Senior High School graduation invariant basic competencies, in order to master and able to apply the accounting basic concepts, principal and procedure in a good way, whether for continuing to the university or plunge to the society life, so it gives the advantages for the students' real life [3]

For so long our education still has an opinion that the science and knowledge only able to be got by memorizing and counting, teachers to be the primary sources for science and knowledge then delivering a speech as the primary choice method of learning and most of the 
students had not to study preparation when they came to school. The reality, many students have who have problems in learning lesson at school. Several cases of that problems or difficulties such as: material that is taught no link with the real life day by day, the way to present the lesson tend to monotonous, boring and not variation so students can't relate/link between what have they learned with how to use the advantages in real life.

The fact at the field also showed that learning that is done by the teachers so far remain the same in accounting learning presentation, such as: (1) It is begun with theory/definition teaching, (2) continued with giving items examples and (3) then items exercises. Actually, in the learning process teachers can use the environment as a learning base, because it can help teachers and students for achieving the learning target [15]. The same thing chese to active by LSM/NGO (Non-Gonernment Organization) Sari in conducting learning process [14]. In the learning process with environment, base can also make the students be independent. It is same with the problem based learning. The research results showed that the class condition to be active, creative and able to increase the students' independence attitude [25]. Soebakri' opinion [9] mainly "Teachers should leave routinely/routine ways in learning, but make more creativity professional development programs." Besides that, the wrong understanding of management function will influence learning management. Kirkham states that "Teachers feel have taught in a good way, even though they can't show the reasons of that assumption"'[8]. The wrong assumption makes many teachers acted unprofessionally in learning, whether in planning, conducting and evaluation.

Therefore in accounting learning management, accounting materials that have particular/unique characteristic need learning management properly, so it is the duty of teachers for creating effective and efficient learning management. Based on that mentioned above, so the problems studied in this research is how the accounting learning management that is done by the accounting teachers of Senior High School at Surakarta City Central Java.

\section{Method}

This research totally used research and development approach. This research and development is a process for developing the existing product and can be the responsibility [20]. The research location is in Senior High School at Surakarta city. The research subject is Senior High School accounting teachers at Surakarta city. Data gathering method uses interview, observation and documentation. Data analysis technique uses interactive analysis that is including data gathering, data reduction, data display and verification [11]. Data validity uses triangulation method and sources.

\section{Result and Discussion}

\section{A. The Planning of Accounting Learning Conducting in Senior High School at Surakarta City}

The planning arrangement of learning conducting (RPP) should be in line with syllabus and curriculum that is established. Teachers' activity in learning material arrangement refers to basic and standard competence that is written on syllabus. The syllabus development in the form of that planning of accounting learning conducting that is taught by teachers in the classroom. A teacher should has planning in 
conducting teaching learning process, if teacher does not arrange RPP, so the teaching learning activity in the classroom will never succeed in a good way and create the clear cut in the classroom.

As on the interview, observation results showed that generally, the accounting teachers in Senior High School at Surakarta city had not developed the planning of learning conducting (RPP) accounting independently. All of the teachers have made syllabus and RPP, but accounting teachershave not able to build a syllabus. Actually, teachers can make syllabus that can be suited with the school condition, students and environment. Therefore accounting' teachers can develop syllabus actively, independently and creatively. It isn line with BNSP [22], that syllabus developer: (1) can be done by the teachers independently or from MGMP and education department, (2) if teachers can recognize the students' characteristic, the condition of school environment, the syllabus can be arranged by themselves independently.

In contextual learning, RPP (Rencana Pelaksanaan Pembelajaran/the planning of learning conducting) refers to personal than reporting to the headmaster/supervisor insteael to personal plan than as to the headmaster/supervisor like what has been done for this time being. RPP tend to be more functioning to remind the teachers themselves in preparing the tools or media and controlling the stages (scenario) of learning. Before doing the contextual learning activity, the teachers preparing learning planning. This planning as the part of teaching preparation. The plan in the learning model form that describes the conducting plan from the beginning until the end of learning for one basic competence. One basic skill can be written in one or more RPP. The teachers use that learning model as the guidance of teaching strategy for achieving the learning goal.

In conducting contextual learning divided into three stages mainly: introduction, core/body of content and closing. The introduction stage, almost all of the teachers almost have conducted it in a good way. The core stage including: (1) Teachers propose the contextual problem that is linked with the material which will be studied, (2) Students try to find the answer for the contextual problem thyat is asked by the teacher, (3) Teachers to facilitate students to do investigation and find the problem solving by themselves, (4) Teachers give an oppurtunity to students to build up their own skill and knowledge, (5) Teachers develop the students' skill to ask, (6) Teachers present the inovative learning model.

Based on the observation of accounting teachers in Senior High School at Surakarta city have not accustomed to propose the contextual problem so that the students lack routine to find and apply their ideas in contextual learning. The questions that is conveyed by the accounting teachers has not fully can be thought real at the students' thinking. Teachers have been habitual to use speech method, giving all of the knowledge to the students previously, then giving the items that have linked with the basic competence that is explained. Therefore the students to be dependence to no as effort to look for the solution of the problem. Teachers have not given opportunity to the students to find the skill and knowledge for their own. This is in line with Lynch and Dorothy' opinion (in [13]), that learning is not only transferred the science but also the process of knowledge consumption. Studying is a process, not merely to memorize the ready concept, but should be experienced by themselves. The students should construct themselves step by step, giving the meaning of that concept through the application to the other field, even to face the students' real life. 


\section{B. Accounting Learning Strategi in Senior High School at Surakarta City}

Accounting learning conducting in Senior High School at Surakarta city has not done optimally. It is because the teachers have not fully understood and master contextual learning. Accounting learning with contextual strategy is excellent to be applied in the accounting learning process because will make the science and knowledge more recorded in the students' memory, but in the conducting teachers face the problems. The problems that will be faced by the teachers in conducting contextual accounting learning are: (a) Teachers still facing difficulty in formulating learning scenario or learning planning step by step of students' activity. (b) The lack of understanding of how to link between learning material with the students' real situation or the knowledge that is owned by the students. (c) The material and the insufficient students' competence. As a result, the process of learning to be blocked, because the students have not ready, (d) to use computer and LCD, the learning process still far from enough. Teachers recognized the importance of media usage in accounting learning, those are; (1) to ease the students to receive the material to be taught, (2) Senior High School students much more need the real media, (3) can be faster to undestand the concept. Dealing with the problems can be overcome by activating the lesson teachers' cooperation (MGMP) that exist in the city. The existing activity in MGMP can be used for finishing the problems that are faced by the teachers in conveying learning material to the students.

\section{The Lesson Management in Accounting Learning in Senior High School at Surakarta City}

The teachers' activity to arrange the learning material refers to the primary and standard competence that is written in syllabus. The syllabus development in the form of planning of learning conducting IPS especially in accounting lesson, the accounting learning that is written in the planning of learning conducting (RPP) that will be taught by the teacher in the classroom. A teacher should have planning in conducting the teaching learning process, if teacher does not arrange RPP so the teaching learning activity in the classroom will never be succeed in a good way and will arise up the clear cut in the classroom. The RPP arrangement should be suitable with the syllabus and the established curriculum.

The lesson material management should be in line with is planned by the teacher to achieve the goal so that students can reach up to the completing criteria minimum (KKM) that is determined by the school. The teachers should be able to master the accounting material, because accounting much computations to enter transactions to be booked for financial reporting that is finally the students can think creatively, skillful and know in the world job, especially in the accounting field. Senior High School curriculum at Surakarta city still using two curriculums, those are; Kurikulum Tingkat Satuan Pendidikan (KTSP) and curriculum 2013. This is relevant with Kirkham' research that is said curriculum approach can increase the effective learning and good experiences to understand accounting that is in line with curriculum and as a good approach for the students to learn to account [8]. It can be meant that curriculum approach for increasing learning experiences in accounting and the students' study achievement.

The completing material for the students is begun from simple until the complex, such as: doing journal items, ledger, help book, worksheet then to be one as the reporting financial. The accounting material very needs the high accuracy and analysis Material in the recording that is begun from transactional analysis proofs to the providing journal in that material. The accounting material often and much study, transactional intrepretis events that will be recorded as in line with the recognition principles and measurement from each element concept of financial reporting in one accounting period. The conducting in bookkeeping on 
accounting learning is going on and then be practiced in bookkeeping to determine the profits and loss level of the company.

Teachers in teaching should use the guide books, such as (a) Printing material, (b) learning material audio, (c) learning material visual, (d) learning material interactive in order teachers can know that in teaching have suitable with the certain criteries and the guidance books that are in line with the established curriculum [24]. The learning material management in Senior High School at Surakarta city has not completed good, so that is needed the increasing of teachers' creativity in order students like accounting learning and satisfied towards the learning material in the classroom. The main target of teaching learning is the lesson material. The successful of teaching learning can be measured by how far the students can master the learning material that has been conducted by the teachers. The learning material itself is the knowledge that a source from the lesson that has been conveyed at school. While the lesson itself is the human being experiences in the past that is arranged systematically and logical, then be explained in many lesson books and finally, the contents of the books should be mastered by the students, [25]. Therefore, the teachers' duty should make the students understand and master accounting lesson that is in line with the content of the established books, especially the accounting lesson. The teachers should be able to transfer the science and knowledge to the students, so that Senior High School students at Surakarta city understand and master the material or accounting lesson that is suitable with the accounting teachers wished. Accounting learning is as learning material that can not be changed anymore because accounting as asset learning in IPS field. Not only accounting learning that should be increased but also the learning teaching too. This is relevant and suitable with the Vincent' research stated that to use accounting learning not only at outstanding schools but also in other schools as well, because the accounting learning is as the general learning [24]. The suitable and clear accounting learning will increase the students' science and knowledge.

\section{Accounting Learning Evaluation in Senior High School at Surakarta City}

Evaluation in accounting learning Senior High School at Surakarta city including, evaluation affective, psychomotor and cognitive the students should own all of them as a continualist of attitude,skill and academic. The assessment evaluation aspects, such as: spiritual to The Inner Most of High Allah SWT. Psychomotoric or skill evaluation, teachers can observe and give an assignment that makes faster thinking way to complete the given duty by the teachers, this evaluation process can be formed in portfolio duty and be conducted while the accounting learning is going on in the classroom. Whereas cognitive assessment in written form, spoken and giving duty that is conducted in daily, mid and final test, The results from the evaluation can be form in the last semester test as the report, and the students know the score of accounting, so that the teachers can understand the students' competence. Before the teachers evaluating of study results, they have to study the curriculum seriously and carefully. This curriculum study is meant to observe and see the study results types that is written in basic competence formulation and indicator. By recognizing that study results types, teachers will choose to determine the evaluation techniques and instruments accurately. For examples: Competence and indicator formulation that contains the cognitive study results in levelling understanding. So the evaluation technique that can be used is objective test multiple choice model or essay. If the study results are psychomotor, so the suitable evaluation technique is attitude test and the instrument use scoring scale from [12]. The accurate scoring for education give the results that are in line with the hope because the assessment is the collecting and cultivating information process to determine the achieving students study results [13]

The assessment in education is critical, because to know the students' competence in accounting learning. Besides, the scoring affectively, psychomotoric and cognitive, the 
scoring that is done by the lecturers to students can be formed in formative test that is directed to improve the teaching learning process that has been done in the final semester discussion of the main topic, whereas summative test that is directed to determine the progressing score or the students study results. The evaluation is to know the final result in teaching learning process that is involved the knowledge, skill, attitude, and values that can be formed in thinking and acting habitually. It will make the students get high spirit and motivation in learning to account to achieve the best results in understanding accounting.

Evaluation in learning accounting so variant so that it do not make boring, like the evaluation in the duty and group form, that things make the students to have more spirit and motivation for studying and understanding accounting. The unity learning Evaluation, as the achieving scoring of the students' basic competence that is conducted based on indicators. The scoring is used by using test and non test both in spoken or written. The attitude' observation, attitude measurement, the assessment of assignment/duty, project and or product, portfolio usage and self assessment [10]. From the stages aspect evaluation that is conducted both in the planning stage and performing. Whereas from the target aspect, evaluation is focused on process and learning product.

The goal of evaluation is to know the students' absorption in accounting learning towards material that is given by the teachers in the items form to know the students' competence. The assessment by giving the certain items will give the effective and efficient measurement that can able to give the best results as in line with KKM and increase the accounting learning quality. The accounting learning evaluation also a variant, such as. Evaluation is conducted in group and individual, group evaluation is based on the group' score. Whereas individual evaluation is based on individual' score/results both in spoken, written or the duty given.

Curriculum has grown up as the importance factor in preparing the accounting students for the future job. In a conceptual frame, it is proved that to offer several potential advantages for evaluation curriculum design and future research can give tighter examination from the framework of many developmental stages. Viewed from the quality has shown the potential that is used to determine relevance curriculum on the topic level every week and maybe as the approach that is used by the researcher to discover several useful scoring criteria the students like scoring criteria in Laing' accounting [6]. Interaction from computer application can develop the students' evaluation about the scoring of accounting attitude; the accounting scoring also uses a computer is very effective that has been applicated in the curriculum level. It is meant that the scoring from Laing to show up on curriculum level at the students' attitude evaluation, similar with Senior High School at Surakarta city based on the existing of KTSP curriculum or 2013 curriculum. The evaluation that is done by the accounting teachers has suitable with the established criteria. The scoring in Senior High School at Surakarta city excellent from the group job results, portfolio or individual duty have achieved the established minimum scores. The scoring results are in the daily, intermediate and final test results. The results that are obtained by the students on accounting learning much satisfaction, because in Senior High School at Surakarta city have been used the useful teaching-learning model to increase the science and knowledge, the students' understanding to achieve the wished and hoped results. The evaluation that is done by the accounting teachers has been in line with the established scoring criteria. 


\section{Conclusion}

The accounting learning management that is conducted by Senior High School accounting teachers at Surakarta city is begun with the planning of learning attendly that refers to the syllabus, teachers have not maximally developed the plan of education leading independently. Most of attendly of acounting learning still tend to use speech method, in giving duty/task and items' exercises. The teachers still having problems in contextual accounting learning, teachers have not fully to understand and to master contextual acccounts learning. Teachers have not been accustomed to link the learning material with the problems of the students' real life. Interaction management begins to enter the classroom until the closing activity more be dominated by the teachers center. The learning material management is conducted based on the academic calendar that is established by the headmaster. The learning Evaluation is conducted in spoken, written and duty/task' giving.

\section{References}

[1] Learning American Accounting Association DOI:10.2308/iace.2010.25.4.613. Vol.25.N0.4 2010pp. 613-629.

[2] Depdikbud., 2014. Materi Pelatihan Guru Implementasi Kurikulum 2013 Tahun Ajaran 2014/2015, Jakarta: Penerbit BPSDMPK dan PMP.

[3] Hasan, Said Hamid. (2000). "Pengembangan kurikulum berbasis masyarakat". Makalah seminar nasional pengembangan program pendidikan berbasis kewilayahan menyongsong diterapkannya otonomi daerah, 31 Agustus 2000 di UPI Bandung.

[4] Kirkham, Ross 2013. An Approach to Improving the Learning Experience for First Year Accounting Currriculum University of the Sunshine Coast, Australia. E-Journal of Business Education \& Scholarship of Teaching. Vol. 7, No.1. 2013, pp.74-81.

[5] Lestianto. 2011 Implementasi Model Pembelajaran Kooperatif CIRC berbasis lesson Study untuk meningkatkan asil belajar siswa untuk mata kuliah kewirausahaan. Malang: FE, UM.

[6] Miles, Matthew B. dan A. Michael Huberman. 1992. Analisis Data Kualitatif. Terjemahan Tjetjep Rohendi. Jakarta: Penerbit Universitas Indonesia.

[7] Ninih Rochanah dkk. 2012 Pengembangan Model pembelajaran Berorientasi Konstruktivistik Untuk Meningkatkan Kualitas Pembelajaran Akuntansi di SMA, Jurnal Pendidikan

[8] O'Leary, Conor dan Stewart Jenny, 2012. J Bus Etthics Accounting and Law Discipline, Griffith Business School.The Interaction of Learning Styles and teaching Methodologiesin Accounting Ethical Introction, Nathan Campus, Griffith University, 170 Kessels Road, Nathan, dan Griffith University, Logan Campus, Logan Australia 113: 225-241

[9] Riccio, Edson. I. dan Sakata, Marici, C.G.2005 Teaching Learning Method In Accounting Education-an Empirical Research In the Brazilian Scenario Brazil: University of sao Paulo. P.1-14

[10] Sarjono, Yetty dan Suyatmini. 2011 Model penataan Pedagang Kaki Lima di Surakarta Sebagai Solusi Konstruktif Untuk Pemberdayaan Tingkat Pendidikan Anak-anak PKL, EDUKASI, Jurnal Ilmu pendidikan Vol. 10. No. 2. Hal.1-8

[11] Sarjono, Yetty. Dan Suyatmini. 2013. Pengembangan Model Pembelajaran Ekonomi Berbasis Lingkungan Dengan pendekatan pembelajaran Inovatif di SMA Muhammadiyah di Surakarta, Laporan penelitian Pentaspena, Juni 2013

[12] Sutama. 2012. Metode Penelitian pendidikan (Kuantitatif, Kualitatif, PTK, $R \&$ D) Gumpang -Kartasura: Fairus Media.

[13] Suwarni, Endah, Retno Widiastuti, dan Anna Isrowiyah. 2007. “'Accelereted Learning' sebagai Dasar untuk Meningkatkan Efektivitas dan Efisiensi Proses Balajar Mengajar Akuntasi Pangantar". Makalah Simposium Nasional 2007. Jakarta 26-27 Juli 2007. Pusat Penelitian Kebijakan dan Inovasi Pendidikan, Badan Penelitian dan Pengembangan, Departemen Pendidikan Nasional Republik Indonesia.

[14] Vincent. 2012. International Journal For Lesson And Learning Studies Using Learning Study To Improve The Teaching And Learning of Accounting in a School In Brunei Darusalam Vol 1. No.1 2012. P. 23-40 
[15] Wafroturrohmah dan Suyatmini, 2008. Penggunaan Metode Problem Based Learning Untuk meningkatkan Kemampuan Belajar Mandiri Mahasiswa Jurusan Pendidikan Akuntansi Pada Mata Kuliah akuntansi Perpajakan, Jurnal Varia Pendidikan Vol. 20.No. 2 Desember 2008 Hal. 154-163 